\title{
LATIN AMERICAN STUDIES
}
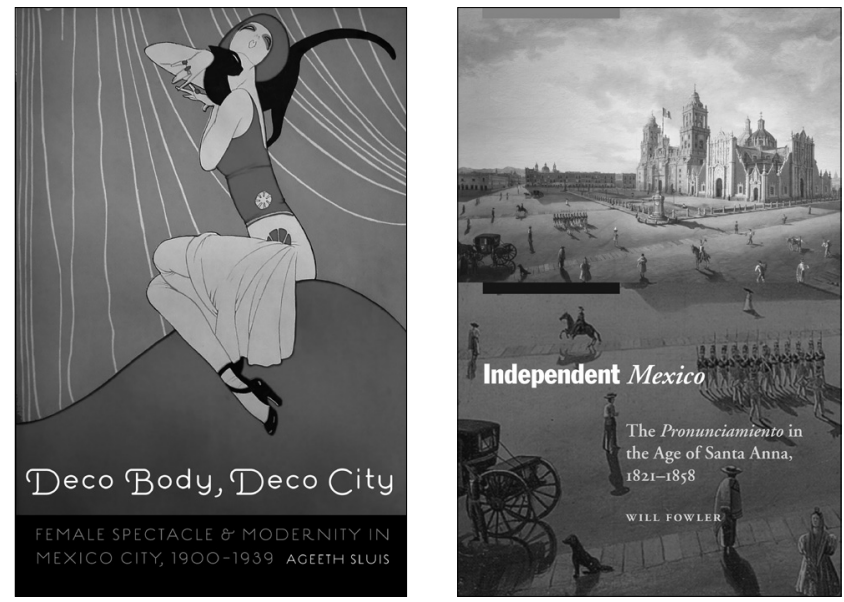

Deco Body, Deco City

Female Spectacle and Modernity in

Mexico City, 1900-1939

Ageeth Sluis

$\$ 35.00 \cdot$ paperback

Part of the Mexican Experience series

\section{Independent Mexico}

The Pronunciamiento in the Age of

Santa Anna, 1821-1858

Will Fowler

$\$ 40.00 \cdot$ paperback

Part of the Mexican Experience series

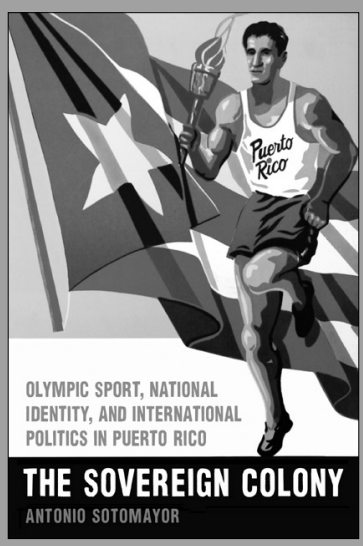

The Sovereign Colony

Olympic Sport, National

Identity, and International

Politics in Puerto Rico

Antonio Sotomayor

$\$ 60.00 \cdot$ hardcover

Forthcoming February 2016

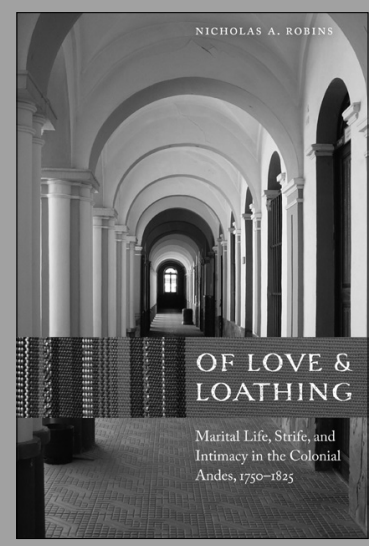

Of Love and Loathing Marital Life, Strife, and Intimacy in the Colonial Andes, 1750-1825

Nicholas A. Robins

$\$ 60.00 \cdot$ hardcover

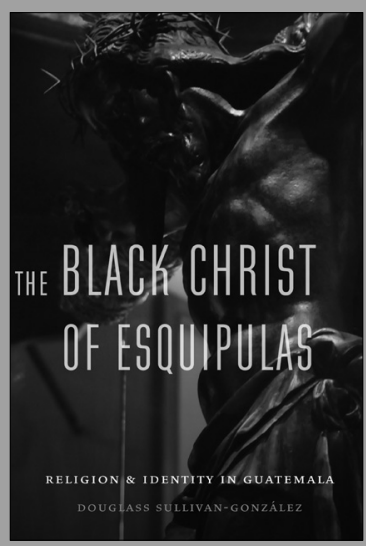

The Black Christ of

Esquipulas

Religion and Identity in

Guatemala

Douglass Sullivan-González

$\$ 55.00 \cdot$ hardcover 
The Americas: A Quarterly Review of Latin American History (ISSN: 0003-1615) is published four times per year, in January, April, July, and October by Cambridge University Press, 32 Avenue of the Americas, New York, NY 10013, USA. Editorial offices for The Americas are located at 3250-60 Chestnut Street, Room 3025, Drexel University, Philadelphia, PA 19104. Printed by the Sheridan Press, Hanover, Pennsylvania 17331. Articles are indexed in American History and Life, Hispanic American Periodicals Index, Chicano Periodical Index, Humanities Index, Social Sciences Index, Social Science Citation Index, and other major references. Instructions for Contributors and Book Review information can be found at journals.cambridge.org/TAM. Opinions expressed are the responsibility of the contributors.

The subscription price of Volume 73 (2016) including delivery by air where appropriate (but excluding VAT), is $\$ 180(£ 120)$ for institutions print and online; $\$ 162(£ 110)$ for institutions online only. Individual subscriptions are available at $\$ 50$ for print and online, $\$ 45$ for print only, and $\$ 35$ for online only. Student subscriptions are available for $\$ 25$, online only.

Orders, which must be accompanied by payment, may be sent to a bookseller, subscription agent or direct to the publisher: Cambridge University Press, Journals Fulfillment Department, 32 Avenue of the Americas, New York, NY, USA; or Cambridge University Press, UPH, Shaftesbury Road, Cambridge CB2 8RU, England. Alternatively, you can place an order online at <journals.cambridge.org/tam>.

For single issues, please contact subscriptions_newyork@cambridge.org.

\section{Advertising}

For information on display ad sizes, rates, and deadlines for copy, please visit the journal homepage at <journals.cambridge.org/tam> or contact USAdSales@cambridge.org.

ISSN: 0003-1615

EISSN: $1533-6247$

Copyright $\odot$ Academy of American Franciscan History 2015. All rights reserved. No part of this publication may be reproduced, in any form or by any means, electronic, photocopying, or otherwise, without permission in writing from Cambridge University Press. Policies, request forms and contacts are available at: http://journals.cambridge.org/action/rightsAndPermissions

Permission to copy (for users in the U.S.A.) is available from Copyright Clearance Center http://www.copyright.com, email: info@ copyright.com.

Postmaster: Send address changes to The Americas, Cambridge University Press, 32 Avenue of the Americas, New York, NY 10013, USA. 


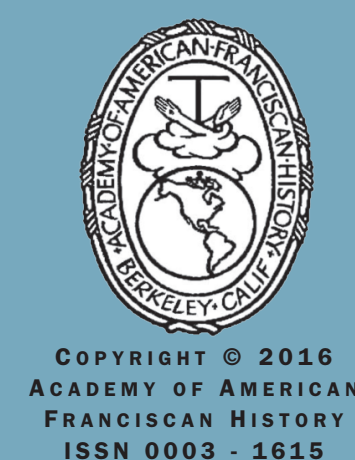

